\title{
Factor Influencing Crude Palm Oil (CPO) Biodiesel Supply in Indonesia Using Error Correction Model $(\mathrm{ECM})$
}

\author{
Larasati Sukmadewi Wibowo \\ Master Degree on Double Degree Program in Brawijaya University, Indonesia \\ National Pingtung University of Science and Technology, Taiwan \\ E-mail: larasathee_ced27@yahoo.com
}

Received: February 10, 2015 Accepted: March 2, 2015

doi:10.5296/ber.v5i1.7070 URL: http://dx.doi.org/10.5296/ber.v5i1.7070

\begin{abstract}
Indonesia is in a good position to develop biodiesel industry for alternative energy supply. The government issued legislations to accelerate the development of biodiesel industry. However, the growth was relatively slow and unstable, especially during the initiating stage of the new policy. The purpose of this study was to know the factors affecting supply of biodiesel in Indonesia, using Error Correction Model (ECM) to determine the long term and short term relationship. Monthly data from January 2010 to December 2013 was used for the estimation. The results showed that in the short term, the price of biodiesel and production capacity has a significant influence on the supply of biodiesel in Indonesia. In the long term, production capacity, price of CPO, and supply of biodiesel in previous year has a significant influence on the supply of biodiesel in Indonesia. The coefficient of Error Correction Term (ECT), which showed how quickly equilibrium is reached again into the long term equilibrium, was estimated -0.0310 indicated that disequilibrium in the previous period corrected in the current period amounted to 3.10 percent. Biodiesel supply elasticity in short term tend to elastic because quantity of supply in the short term is not too sensitive to price changes. Biodiesel supply elasticity in short term tend to inelastic, which if there is a change in these variables will not cause great shock on the level of biodiesel supply in Indonesia.
\end{abstract}

Keywords: Error Correction Model (ECM), Biodiesel supply, Biodiesel price, Price of CPO, Production capacity

\section{Introduction}

Energy resources such as of oil and gas are the largest contributors of foreign exchange export 
proceeds for Indonesia. Needs for domestic fuel oil has been increasing with the national economic development. Today, the energy consumption from fossil reached $54.4 \%$. Dependence on fossil fuels brings threats including depletion of petroleum reserves, the rate of price increases due to greater demand, and increased production generated more greenhouse gas emissions (Sadewo, 2012).

On the other hand, oil reserves in Indonesia is limited because it is a non-renewable resource. Therefore, efforts should be taken to look for alternative fuels. Biodiesel emerged as an alternative energy after the energy crisis. In 2005, energy demand on diesel and kerosene in Indonesia reach 42 million liters or $65 \%$ of the total consumption of petroleum. In 2005-2007, the consumption of diesel in Indonesia reached an average of 13 million metric tons per year. Two percent of diesel oil consumption in 2007 was derived from palm oil and castor oil.

The study conducted by Damayanti (2008, cited in Sadewo, 2012) showed that the biofuel industry in Indonesia was still at the introduction stage, which was characterized by low sales and prices for consumers were still not competitive compared with subsidized fuel. In order to support the development of biodiesel, the government has set a policy in the form of a Presidential Decree Number 5 of 2006 on the National Energy Policy with the purpose of realizing the security of energy supply in the country. The biofuel is in the form of biodiesel, bioethanol and bio oil. The questions of particular interest and this research want to address are:1) What are the factors that influence supply of biodiesel in Indonesia? 2) What are the implications that affecting supply factors of biodiesel in Indonesia? And 3) How the level of elasticity supply of biodiesel in Indonesia?

\section{Literature Review}

Due to the depletion of fossil fuel which leads to high gasoline and diesel prices, the utilization of renewable energy, such as biodiesel becomes increasingly pressed and important. As of November 2008, there were 11 commercial scale biodiesel producers in Indonesia and further three producing less than 1000 ton per year. Total production capacity was 1.6 million ton. Biodiesel plants (ton per year). All biodiesel was produced from crude palm oil (Legowo, 2008).

Palm oil is likely to be the main biodiesel feedstock in Indonesia for some time, given its abundant supply and that Indonesia is a net exporter. Indonesia is the world's leading producer of palm oil, and the second largest exporter (after Malaysia). In 2008, the Indonesian industry is forecast to produce almost 20 million ton of palm oil, overtaking Malaysia as the world top producer. Around five million ton expected to be consumed domestically, mostly as raw material for cooking oil, while the remaining 15 million ton will be exported. Exports of CPO were valued at over US\$ 8 billion in 2007. The land under palm oil cultivation in Indonesia has expanded ten fold since 1985, covering more than 6.8 million hectares by June 2008 (Legowo, 2008). It is expected to reach 10 million hectares by 2010. Production is dominated by a few large plantation operators, an estimated 30 percent of which are currently controlled by Malaysian interests (Guerin,in Dillon et al).

Based on Indonesia industry of biodiesel review, The Indonesian Government has been 
primarily motivated by the potential of biofuels to increase rural employment, raise incomes for farmers, improve energy security and develop a new export industry. The stated objectives of other governments that biofuel policies usually also include reducing greenhouse gas emissions or urban pollution (Timilsina, 2010). In addition, other advantages for developing biodiesel in Indonesia are new investment and export opportunities are expected to trigger the growth of energy, availability of new jobs both in plantations and factories, build strength in agriculture as Indonesian forces and the latter is the reduce of poverty. This research in order to achieve and to know what factor are most influence on the supply of biofuel, so that can give a suggestion to solve the problem about decreasing of some biodiesel industries in Indonesia for the future.

To support developing biodiesel industry in Indonesia, the government made targets to some sectors that use biodiesel. It is called the "obligations" for biodiesel utilization. The sectors include Public Service Obligation (PSO) transportation, non-Public Service Obligation (non-PSO) transportation, industrial and commercial, and electricity generation. In October 2008, the Indonesian Government passed the legislation that makes biofuel consumption mandatory, commencing in 2009.

Supply is a relationship that shows many kind number of goods that provide by the producer to sell again by the various alternative price, during a specific time period. The supply curve is a curve that shows the relationship between the price of a particular item and the quantity of goods offered. Factors that affect supply are commodity price, other commodity price, technology, and production capacity. In the commodity price and other commodity price, have a relationship between change in price and change in quantity can be expressed in supply elasticity. There are two factors that can affect the elasticity of supply are production capacity and price changes occur over time. The greater production capacity within a certain time of getting input, then the elasticity relatively large, with the formula:

$$
E_{s}=\frac{\Delta Q / Q}{\Delta P / P}=\frac{\Delta Q}{\Delta P} \times \frac{P}{Q}
$$

Where:

Es : Supply elasticity

Q : Number of supply goods

$\mathrm{P}$ : Price of the goods

$Q \quad$ : Changes in supply quantity

$P$ : Changes in the price of goods

If :

Es $>1 \quad$ : Elastic

Es $<1 \quad$ : Inelastic

Es $=1 \quad$ : Unitary elasticity

ECM is a dynamic model which is widely applied in the economic analysis. The concept of ECM was first introduced by Sargan and Gujarati in 1964 (Hafizah, 2009). This model aims to overcome the problem of the problem of time series data are not stationary and spurious 
regression. Also address the issue of consistency difference between short-term forecasting results with long-term by means of the proportion of disequilibrium in one period is corrected in the next period, so that no information is eliminated through the use for long-term forecasting (Lee, 2013)

\section{Methodology}

This secondary data used in this study cover the study period from 2010 to 2013 monthly data of Supply of Indonesia Biodiesel $\left(\mathrm{Q}_{\mathrm{t}}\right)$ is the quantity of biodiesel per Kiloliter, Price of Biodiesel (PB) is the price of biodiesel per Kiloliter in Rupiah currency, Price of Crude Palm Oil (PCPO) is the price of biodiesel material as CPO (Crude palm Oil) per tons in Rupiah currency, Production Capacity (CA) is the targeting production from the industry to produce biodiesel. production capacity can be used as the basis of an industry determine the quantity of production of biodiesel can also be used as one of the evaluation and Supply in Previous Year $\left(\mathrm{Q}_{\mathrm{t}-1}\right)$ is the quantity of biodiesel production one year before year 2010. Based on this analysis use data from 2009 in tons per year.

It was collect from several online databases: Indonesia Central Bureau of Statistics, Ministry of Industry, Ministry of Energy and Mineral Resources, World Bank, Association of Indonesia Biofuel Producer (APROBI), as well as journals. Data used in this research are: biodiesel supply (metric tons), commodity price of oil (CPO) domestic (IDR/ton), Biodiesel price $(\mathrm{Rp} / \mathrm{Kl})(\mathrm{IDR} / \mathrm{Kl})$, and production capacity $(\mathrm{Kl})$.

Data analysis is done with estimation process using ECM (Error Correction Model).ECM is used to determine the effect of short-term and long-term independent variable on the dependent variable. Besides, ECM models are able to handle non-stationary data and spurious regression problems. The spurious regression is characterized by a high $\mathrm{R}^{2}$ but has a low Durbin Watson value (Shocrul, 2011). There are several conditions for using the ECM model. First, at least one of the variables used are not stationary. Second, the equations used have a cointegration relationship. Third, the equation is univariate. If not all three requirements are met, then the ECM method cannot be used. Thus, conducting stationary test, examining the degree of cointegration and cointegration tests are needed.

The method used is the Engle-Granger cointegration test, which is usually done with a single equation. The stationarity test in this research was based on the Phillips-Perron (PP), which in this test whether or not there of a unit root in the variables at the level of first difference. The test criteria compare statistical values with critical values in the Phillips-Perron table. If the value of the PP statistic is less than the value of MacKinnon Critical Value then the data is stationary. But if the value of the Phillips-Perron statistic is greater than the value of MacKinnon Critical Value then the data is non-stationary. In this research use the natural logarithm (LN) as transformation of variables is one way to reduce the linear relationship between the explanatory variables.

The cointegration test for biodiesel supply can be expressed using equations (2) and (3) :

$$
\mathrm{SB}_{t}=f\left(P B, P C P O, Q_{t-1}, C A\right)
$$




$$
\operatorname{Ln} Q_{t}=\beta_{0}+\beta_{1} \operatorname{Ln} P B_{t}+\beta_{2} \operatorname{LnPCPO} O_{t}+\beta_{3} \operatorname{Ln} Q_{t-1}+\beta_{4} \operatorname{LnCA_{t}}+\mu_{t}
$$

where:

$\operatorname{Ln} Q_{t} \quad$ : Supply of Indonesia biodiesel in year $t(\mathrm{kl})$

$\operatorname{LnPB}_{t} \quad:$ Biodiesel prices in year $t(\mathrm{Rp} / \mathrm{kl})$

$\mathrm{LnPCPO}_{t} \quad$ : Domestic CPO prices in year $t(\mathrm{Rp} / \mathrm{kg})$

$\operatorname{Ln} Q_{t-1} \quad$ : Biodiesel supply in the previous in year $t(\mathrm{kl})$

$\operatorname{LnCA} \quad$ : Production capacity in year $t(\mathrm{kl})$

$\mu_{t} \quad:$ Error disturbance in year $t$

Cointegration vector can be used as Error Corection Term (ECT) if qualifying Unit Root Test testing or testing stationary. Stationarity can be seen from the t-statistic is more lower than the criteria Mac Kinnon. ECT is used is the previous period. It is intended to equate ECT variables with the dependent variable another that uses the natural logarithm (LN) of dynamic or previous period. The ECT coefficient must be negative significant value for the feasible of ECM model use.

The ECM models as following:

$$
\Delta y t=\Delta x t-\lambda\left(y t-\beta_{0}-\beta_{1} x_{t}\right)+\varepsilon_{t}
$$

Where:

$\Delta \mathrm{y}_{\mathrm{t}}=$ First difference $\mathrm{Y}\left(\mathrm{y}_{\mathrm{t}}-\mathrm{y}_{\mathrm{t}-1}\right)$

$\Delta \mathrm{x}_{\mathrm{t}}=$ First difference $\mathrm{X}\left(\mathrm{x}_{\mathrm{t}}-\mathrm{x}_{\mathrm{t}-1}\right)$

$\mathrm{y}_{\mathrm{t}}=$ Endogenous variable

$\mathrm{x}_{\mathrm{t}}=$ Exogenous variable

$\epsilon_{\mathrm{t}} \quad=$ Error term

Note: $\Delta=D$

The result from Phillip Perron test, where the data is stationery at the first differences, the ECM models for Indonesia biodiesel supply as following:

$$
D \ln Q_{t}=\beta_{0}+\beta_{1} D \ln P B_{t}+\beta_{2} \operatorname{LnDPCPO}+\beta_{3} \ln Q_{t-1}+\beta_{4} D \operatorname{LnCA_{t}}+\beta_{5} E C T_{t-1}+\mu_{t}
$$

\section{Results and Discussions}

The normality test using Jarque-Bera came out $>5 \%$, which means the distribution of the data is normally distributed (Figure 1). 


\section{Macrothink}

Business and Economic Research

ISSN 2162-4860 2015, Vol. 5, No. 1

\subsection{Unit Root and Autocorrelation Test}

The unit root test was carried out using Phillips-Perron (PP) Test. Results shown on the Table 3, it can be stated that all variables are stationary in first difference. For autocorrelation, the Breusch-Godfrey serial correlation LM test was used. The value of 0.1483 is more than 0.05 , mean that there is no autocorrelation (Table 4).

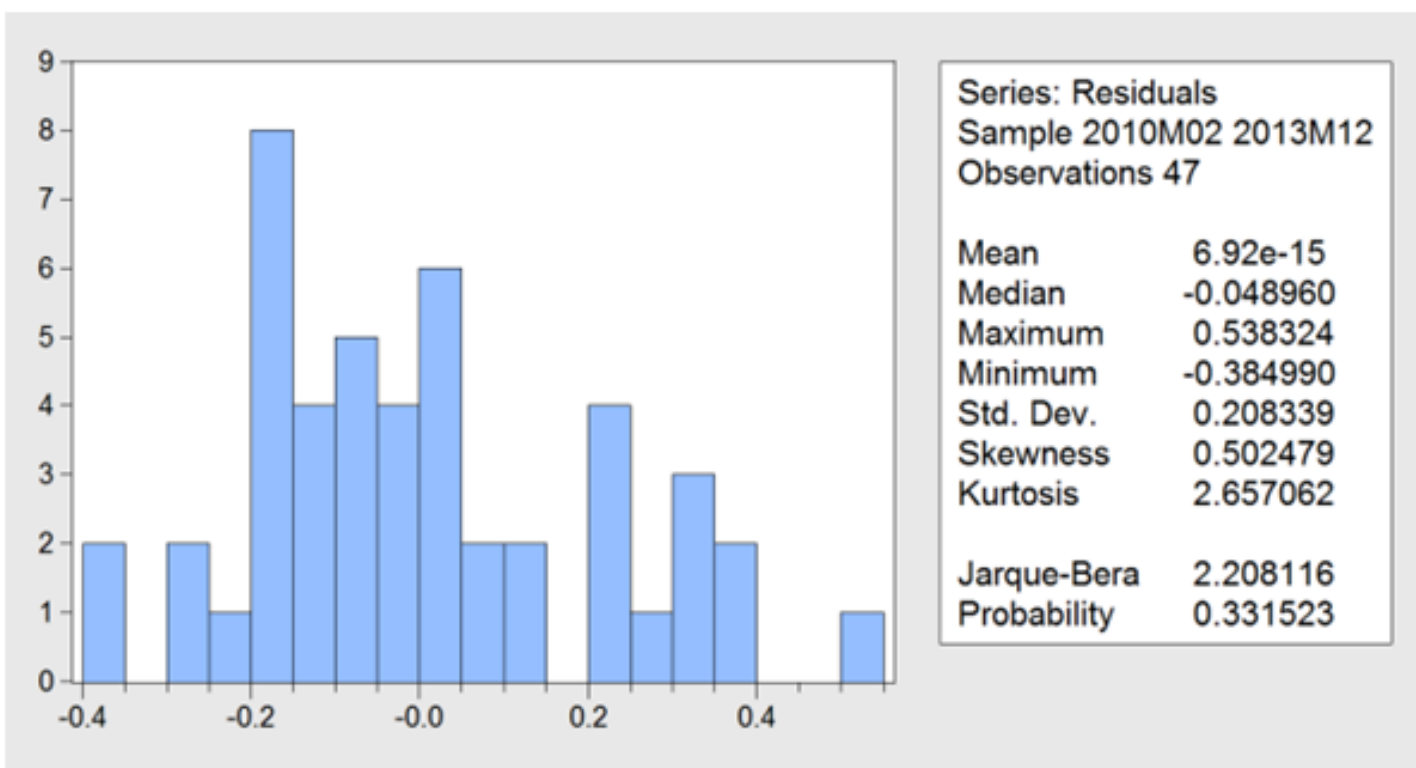

Figure 1. Normality Test

Table 3. Unit Root Test by Phillips-Perron (PP) Test

\begin{tabular}{|c|c|c|}
\hline Variable & PP value (level) & PP value (first difference) \\
\hline LNQ $_{t}$ & 0.5627 & $-3.7107^{* *}$ \\
\hline LNPB $_{\mathrm{t}}$ & -3.0038 & $-9.9851^{* *}$ \\
\hline LNPCPO $_{\mathrm{t}}$ & -1.9445 & $-6.0339^{* *}$ \\
\hline LNQ $_{\mathrm{t}-1}$ & -2.9167 & $-6.7047^{* *}$ \\
\hline LNCAt & -0.57875 & $-3.63650^{* *}$ \\
\hline
\end{tabular}

Note: The Phillips-Perroncritical values for $1 \%, 5 \%$, and $10 \%$ are $-4.1658,3.5085$ and -3.1842 , respectively; $* *$ denotes significant at $5 \%$.

Table 4. Autocorrelation Test

\begin{tabular}{|c|c|c|c|}
\hline \multicolumn{5}{|c|}{ Breusch-Godfrey serial correlation LM Test : } \\
\hline F-statistic & 1.7239 & Prob. F(2,39) & 0.1917 \\
\hline Obs*R-squared & 3.8176 & Prob. Chi-Square(2) & 0.1483 \\
\hline
\end{tabular}




\subsection{The Estimated Results of ECM}

Based on the short term equation it can be seen that value of adjusted $\mathrm{R}^{2}$ is 0.9324 which means that the $93.24 \%$ of supply in Indonesia biodiesel can be explained by the variables used in the model. F-statistic probability value is less than 5\% (Table 5). This shows that at least one of the independent variables has significant effect on the dependent variable.

Table 5. Estimation results of ECM

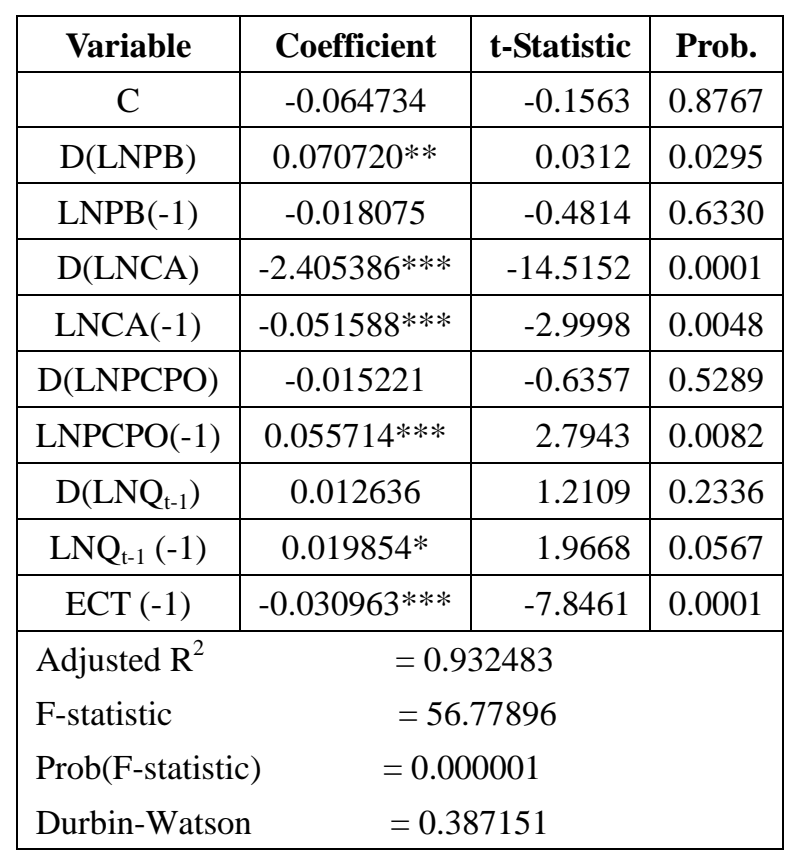

Note: ***,**,* denotes significant at $1 \%, 5 \%$, and $10 \%$, respectively.

Variable $(\mathrm{ECT})_{\mathrm{t}-1}$, the lagged value of the error in the bid price of biodiesel in a previous period, showed a significant negative sign. The cointegration coefficient is equal to 0.0001 . It is clear that ECT has qualified that $0<\mathrm{ECT}<1$ and that means the error correction model can be used to analyze the factors that affect biodiesel supply in Indonesia. The cointegration coefficient is equal to 0.030963 , that the previous period disequilibrium corrected in the current period of 3.09 percent. ECT showed how quick equilibrium is reached again into the long-term equilibrium.

Biodiesel price $(\mathrm{PB})$ showed significant positive sign while Production capacity $(\mathrm{CA})$ showed a significant negative sign in affecting supply biodiesel $\left(\mathrm{Q}_{\mathrm{t}}\right)$. However, $\mathrm{CPO}$ price (PCPO) and Biodiesel supply in the previous year $\left(\mathrm{Q}_{\mathrm{t}-1}\right)$ are not significant in affecting supply of biodiesel. It can be seen from the phenomena which happened in long-term, which production capacity is found from the source of producer industry of biodiesel multiply to the domestic production. But the targeted level of production capacity can not reach the production (Figure 2), and it causes the material price of CPO to increase. So the biodiesel producer will get the high production cost and can cause them no longer want to produce biodiesel. This unstable situation cause producer can not to optimize the production capacity of biodiesel. 


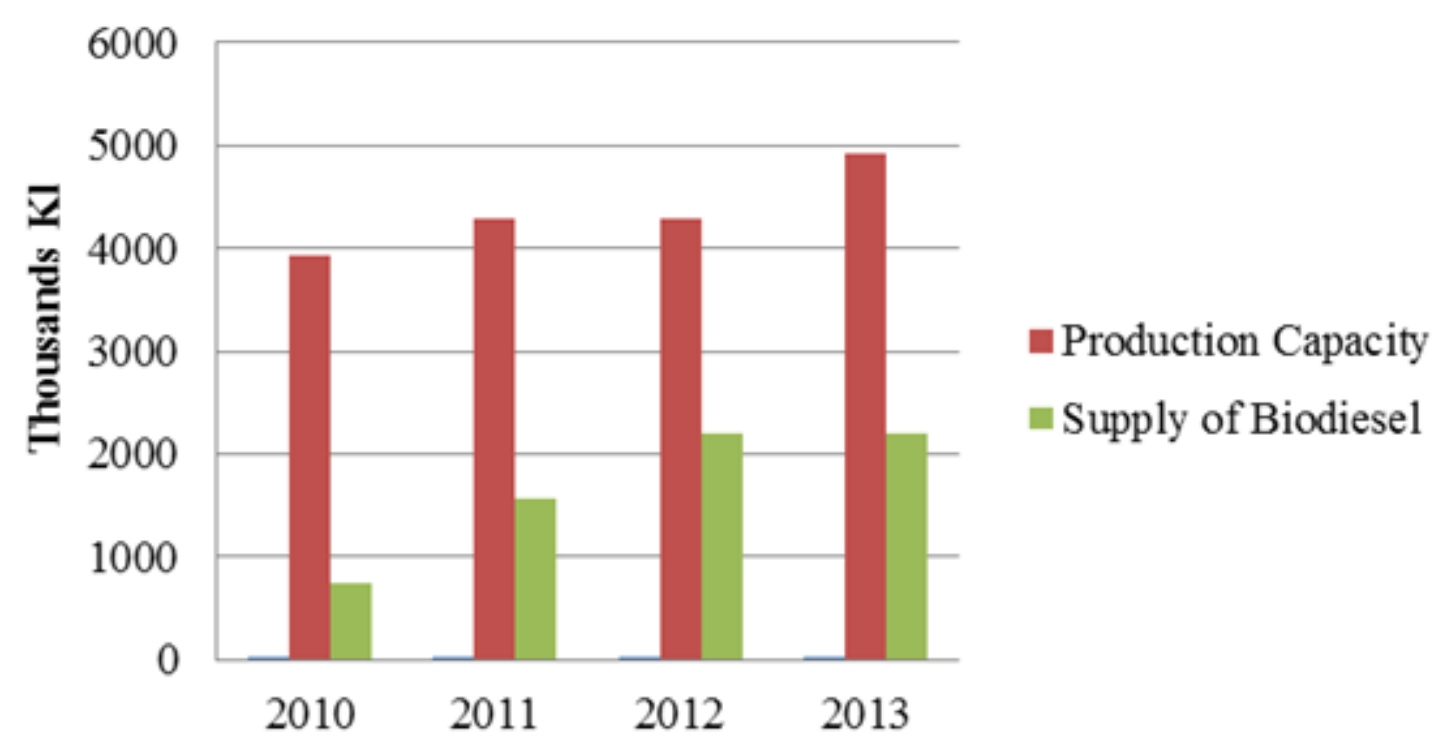

Figure 2. Biodiesel Production Capacity and Production from 2010 to 2013

This situation made only one third of companies of biodiesel still continue their production. Manufacturers continue actively are integrated producers with plantation and palm oil mills. Some manufacturers who are less active were due to constrained in their operations caused by a combination of raw material price fluctuations of CPO, which tended to increase lately. In addition, there are constraints on management, working capital, and limited market scale associated with the budgeted amount of government subsidies for biodiesel program.

The results of other study showed that biodiesel producers currently capable of operating with a good level of capacity utilization as an integrated manufacturer sells its products to the export market as Fatty Acid Methyl Ester (FAME). These products not only use as biodiesel but, among others, can be used as a solvent in the chemical industry and raw material for surfactants that offer more competitive prices.

The data shows the performance of the biodiesel industry throughout 2005-2013 production was positively correlated with government support in the form of regulatory obligations related to mandate biodiesel blends with diesel for market certainty. It also supported the legal law of biodiesel subsidies and pricing mechanism (Investor Daily Indonesia, 2013)

As new industrial products, industrial biodiesel would require more concrete support again in the form of incentives and production technology assistance. It is important to boost the production of biodiesel in the country.

Variable Price of CPO (PCPO) showed a significant positive sign in affecting supply biodiesel $\left(\mathrm{Q}_{\mathrm{t}}\right)$. If the price of $\mathrm{CPO}$ increased in the short-term, assuming other factors constant, the quantity of biodiesel supply $\left(\mathrm{Q}_{\mathrm{t}}\right)$ will increased too. This is not related with the theory, which if the price of CPO material to make biodiesel increase will cause the production of CPO decrease, but the current condition from the analysis result shows that even the price of CPO increasing, biodiesel production also will increasing. It can be seen from the increasing number of palm oil biodiesel demand, which during the last 4 years the demand for biodiesel showed a 
significant increase, reaching $67,000 \mathrm{Kl}$. So by increasing the domestic price of CPO, the company will continue to produce large amounts of palm oil biodiesel, on the diagram as follows in Figure 2 and Figure 3.

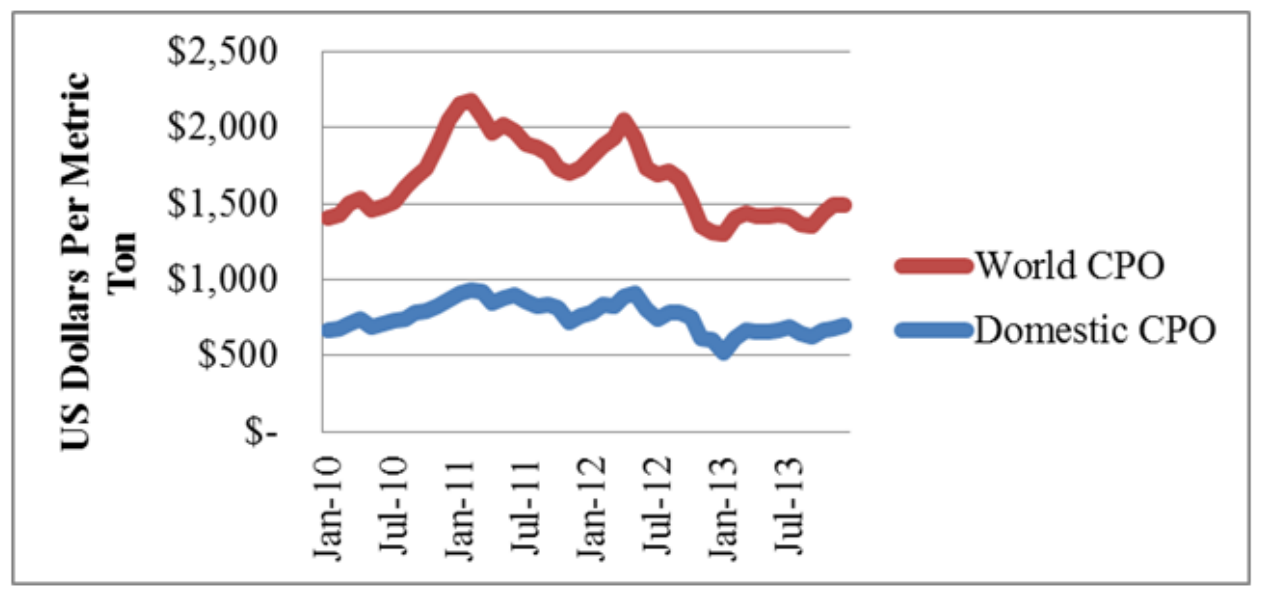

Figure 3. World Price and Domestic CPO Price from 2010 to 2013

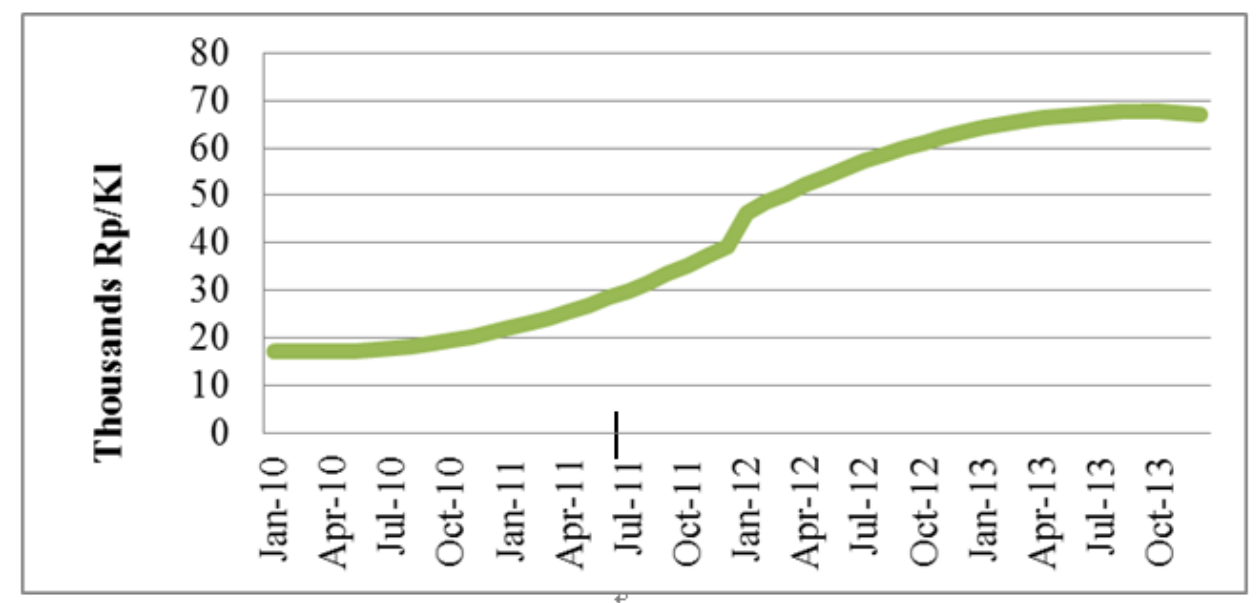

Figure 4. Domestic Biodiesel Consumption from 2010 to 2013

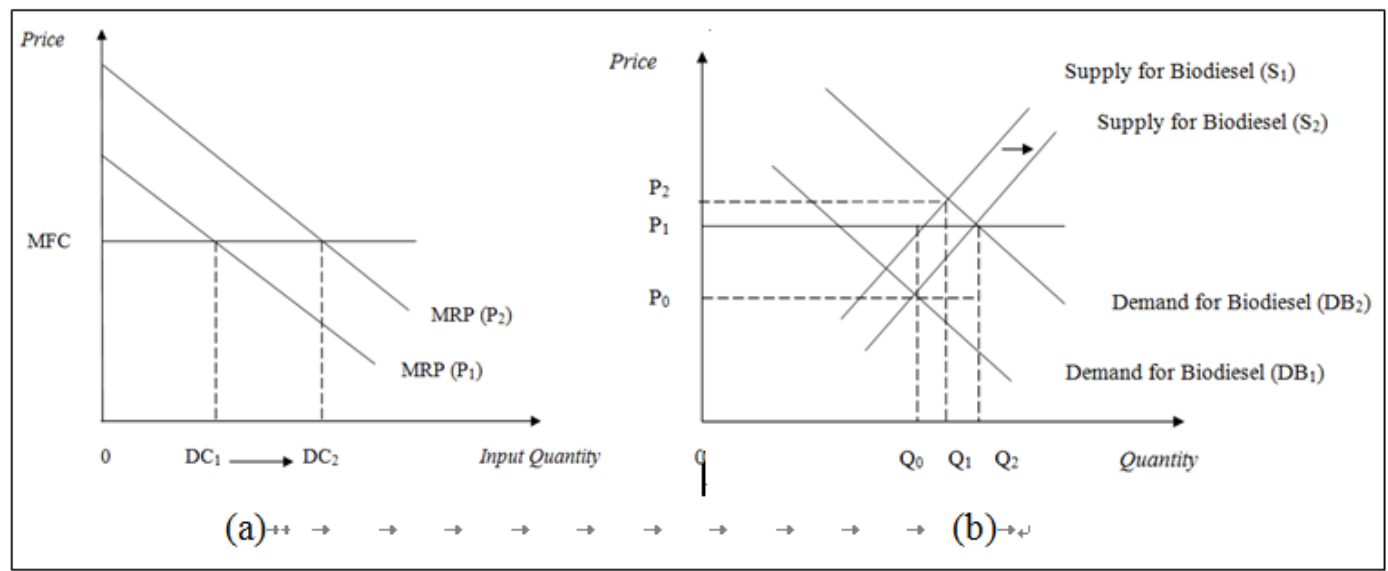

Figure 5. Input Market and Output Market Curve 


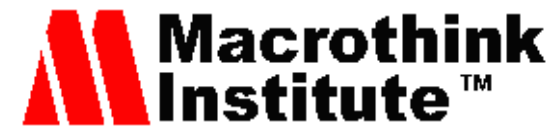

Business and Economic Research

Figure 5 shows input as demand (a) for CPO are the marginal revenue from output demand and the marginal product of the input of CPO. When input demand change in the demand for output market biodiesel. If Demand for Biodiesel increase both price and marginal revenue will go up. The second curve (b) is output market of Indonesia biodiesel. Changes price (become up) from $\mathrm{P}_{1}$ to $\mathrm{P}_{2}$ shift market demand for the output from $\mathrm{DB}_{1}$ to $\mathrm{DB}_{2}$, increasing market price in the short run to $P_{1}$. Because short run supply is upward sloping $\left(S_{1}\right)$, price goes up to $P_{1}$, and the firm sees its marginal revenue product for the input shift out to $\mathrm{DC}_{2}$. It is the quantity for the input (CPO) rises to $\mathrm{DC}_{2}$.

CPO domestic price have unpredictable movement, because sometimes prices can become lower, highly, and dropped until very low price. Beside on Figure 4.5, showed in 2010 price movement increased start from US $\$ 600$ to US \$800. In 2011 CPO price increased highly until US $\$ 900$, but in the end of 2011 moved down become US $\$ 700$. But in the beginning of 2012, the price become decreased from US $\$ 700$ become US \$600. In 2013 reach US \$500 price. This is because CPO price influence by increased of production volume, increased CPO supply but decreased CPO selling to another country or export activity.

Another factor the lower price of raw CPO can caused the investor of CPO and biodiesel producer will not invest and will be difficult to developing biodiesel industry without developing derivative products that more profitable. But to face this situation, government taking responsibility to arrange policy such as restricting the structure export tariff which to the upstream and downstream CPO industry tariff was same. But with restricting, for upstream will be worn export tariff higher than downstream. To support CPO industry, government can give the incentive loan to CPO industry who want to developing biodiesel production.

\subsection{Supply Elasticity}

Biodiesel supply elasticity values can be seen from the predicted values of parameters in the model estimation. Long-term and short-term elasticity values can be seen from the estimated value of parameters in model ECM. Based on the known value of the response turns all the independent variables to supply the Indonesian biodiesel are short-term and long-term elasticity value from Table 5 which in short-term there are two significant factors affecting supply of biodiesel in Indonesia, biodiesel price and production capacity.

Biodiesel supply elasticity in short-term tend to elastic because quantity of supply in the shortterm is not too sensitive to price changes. Biodiesel supply elasticity in short-term tend to inelastic, which if there is a change in these variables will not cause great shock on the level of biodiesel supply in Indonesia.

\section{Conclusion}

The development of palm oil biodiesel in Indonesia is quite significant. This is indicated by the increase of production capacity each year for the biodiesel industry to continue to seek rather the production of biodiesel continues. On the other hand, increased domestic consumption of biodiesel in Indonesia encourages biodiesel industry in Indonesia to continue to develop the production of biodiesel CPO. The factors that affecting biodiesel supply are price of biodiesel, price of CPO, and production capacity of biodiesel before selling to the consumers. Even 
though there are only 5 firms of biodiesel industry in Indonesia still active, but they are huge firms which have the land of palm oil producer and until now it can fulfill consumer needs.

\section{Recommendation}

Long term implication of CPO price must controlled by government. Export tariff and give incentive to CPO industry who want to developed biodiesel will be more efficient to face high and low of CPO price. So, even in high price CPO industry with biodiesel could still produce biodiesel as well. Long-term biodiesel production and production capacity must balancing in order to reach targeting for the domestic consumption and minimize idle capacity of the production capacity.

\section{Acknowledgement}

The authors would like to express their thanks to the following organizations for the opportunity to present the paper: Department of Agribusiness Management, National Pingtung University Science and Technology, Taiwan; Brawijaya University, Indonesia.

\section{References}

Data Center and Information System of Agricultural. Accessed 14 June 2014. From http://pusdatin.setjen.pertanian.go.id/tinymcpuk/gambar/file/A1_Jan_Klp_Sawit.pdf No. 01/01/I,7.

Dillon, H., H. S. Dillon, \& T. Laan, Government Support for Ethanol and Biodiesel in $\begin{array}{llllll}\text { Indonesia. } & \text { Accessed } & 24 & \text { December } & 2013 & \text { from }\end{array}$ http://www.iisd.org/gsi/sites/default/files/indonesia_biofuels.pdf, 2008

Hafizah, Meirisa Rezeki. (2009. Supply Analysis of Crude Palm Oil (CPO) with Error Correction Model Approach [Analisis Penawaran Crude Palm Oil (CPO) dengan Error Correction Model]. Indonesia: Thesis. Indonesia: Indonesia University

Investor Daily Indonesia (2013). Boost Biodiesel Industry (Menggenjot Industri Biodiesel). http://www.investor.co.id/energy/Menggenjot-industry-biodiesel/82487. Accessed at 22 December 2013.

Lee, Chun-Chang. (2013). Interactions between House Prices, Stock Prices and Monetary Policy_Using Recursive VAR. http://dx.doi.org/10.4236/ajibm.2013.38074. Accessed at 27 December 2013.

Legowo, E. H., Kebijakan dan Program Pengembangan Bahan Bakar Nabati. Presented in the Workshop on Dissemination Biofuels Development, Ministry of Energy and Mineral Resources (ESDM), 2008

Media Articles Plantation Crops. (2013). Indonesia Expor CPO in 2013 become 13 percentage. Plantation media of Indonesia. Accessed 14 June 2014.

Meher, L. C., Sagar, D. V., \& S. N. (2006). Technical Aspects of Biodiesel Production by Transesterification a Review. Renewable and Sustainable Energy Reviews 10:248-268. www.ijrdet.com. Accessed 14 June 2014. 


\section{Macrothink}

Business and Economic Research

ISSN 2162-4860 2015, Vol. 5, No. 1

Official Palm Oil Information Source USA. Biodiesel Solution.

2008.http://www.palmoilworld.org/biodiesel.html. Accessed at 4 June 2014

Sadewo, Hasmo. (2012). Mandatory Utilization Policy of Biodiesel in Indonesia (Analisis Kebijakan Mandatory Pemanfaatan Biodiesel di Indonesia) Thesis. Jakarta: University of Indonesia.

Sugiyono, G., Policy and Institutional Frameworks for the Development of Palm Oil-Based Biodiesel in Indonesia.Accessed at 24 December 2013.From http://www.cifor.org, 2011

Timilsina, Govinda R, Ashish Shretha. (2010). Biofuels Markets, Targets, and Impacts. Policy Research Working Paper: The World Bank Research Group Environment and Energy Team. From http://elibrary.worldbank.org/doi/pdf/10.1596/1813-9450-5364

\section{Copyright Disclaimer}

Copyright for this article is retained by the author(s), with first publication rights granted to the journal.

This is an open-access article distributed under the terms and conditions of the Creative Commons Attribution license (http://creativecommons.org/licenses/by/3.0/). 